\title{
MENGAPA LATE CHILDHOOD MEROKOK?
}

\author{
Apriyani Taryaka; Evi Afifah Hurriyati
}

\author{
Jurusan Psikologi, Fakultas Psikologi, Universitas Bina Nusantara \\ J1. Kemanggisan Ilir III No.45, Kemanggisan, Palmerah, Jakarta Barat 11480 \\ apriyani_taryaka@yahoo.com \\ e_afifah@binus.ac.id
}

\begin{abstract}
This research is set to determine the cause of late childhood smoking and whether the factor behind late child hood smoking is the same with teenagers. The background of this research are the findings of Tobacco Control Support Center that 3 out of 10 students are found to be smoking before reaching the age of 10. This research uses qualitative case study research through observation and in-depth direct interview towards 3 male subjects aged 11 who smokes every day. Results show that the 3 subjects smoke due to personal factor, friends, family and cigarette advertisements. Most of the factor behind the smoking behavior are found to be in the sociogenic motive category. Therefore, it could be concluded that the smoking behavior of the 3 subjects is not purely from the personal factor, but more of the environmental factor having big part in creating smoking behavior in the 3 subjects. Factors behind smoking behavior of the three late childhood subjects and teenagers have a lot in common. Friend factor is the first driving factor of smoking behavior on both late childhood and teenager.
\end{abstract}

Keywords: smoking behavior, late childhood

\begin{abstract}
ABSTRAK
Penelitian ini bertujuan untuk mengetahui mengapa late childhood merokok dan apakah factor pendorong perilaku merokok pada late childhood sama dengan pada remaja. Hal ini dilatarbelakangi oleh temuan Tobacco Control Support Center yang menyatakan bahwa 3 dari 10 pelajar ditemukan merokok pertama kali sebelum mereka mencapai usia 10 tahun. Penelitian ini menggunakan desain penelitian kualitatif studi kasus melalui observasi dan wawancara langsung secara mendalam kepada 3 subjek laki-lai yang berusia 11 tahun dan merokok setiap hari. Hasil penelitian menunjukkan bahwa ketiga subjek merokok karena factor diri sendiri,teman, keluarga dan iklan rokok. Sebagian besar faktor pendorong perilaku merokok yang muncul pada ketiga subjek termasuk dalam kategori motif sosiogenik. Dengan demikian, dapat disimpulkan bahwa perilaku merokok pada ketiga subjek tidaklah murni muncul atas faktor pribadi, melainkan lebih karena faktor lingkungan yang mempunyai andil besar dalam memunculkan perilaku merokok pada ketiga partisipan tersebut Faktor pendorong perilaku merokok pada ketiga subjek late childhood dan remaja memiliki cukup banyak kesamaan. Faktor teman merupakan faktor pendorong pertama pada perilaku merokok baik pada late childhood maupun remaja .
\end{abstract}

Kata kunci: perilaku merokok, late childhood 


\section{PENDAHULUAN}

Perilaku merokok di kalangan remaja sekarang bukanlah hal baru lagi. Tidak jarang kita menemukan remaja yang masih mengenakan seragam sekolahnya (baik SMP maupun SMA) merokok bersama teman-temannya ataupun sendiri. Menurut Iqbal (2008) persentase tertinggi seseorang mulai merokok adalah pada usia 16-20 tahun, yaitu sebesar 53.1\% dimana usia tersebut menandakan individu tersebut sedang dalam masa remaja. Merokok memang bukanlah hal baru bagi remaja Indonesia, namun cukup mengejutkan bila kita menemukan anak-anak sekolah dasar yang merokok. Fenomena ini sudah mulai banyak ditemukan di Indonesia, terutama di Jakarta. Temuan oleh Tobacco Control Support Center menyatakan bahwa 3 dari 10 pelajar ditemukan merokok pertama kali sebelum mereka mencapai usia 10 tahun. Diantara pelajar yang merokok, sebesar 3,2\% telah kecanduan dengan indikator hal pertama yang diinginkan pada pagi hari adalah merokok (Soerojo, et. al, 2007).

Smet (dalam Komasari \& Helmi, 2000) menyatakan bahwa usai pertama kali merokok pada umumnya berkisar antara 11-13 tahun. Menurut data Komnas Anak, pada tahun 1970 usia perokok termuda adalah 15 tahun, namun pada tahun 2004 usia perokok termuda adalah 7 tahun (Messwati, 2008). Pernyataan diatas turut menunjukkan betapa memprihatinkannya perilaku merokok pada anak di Indonesia. Bahaya yang disebabkan rokok sepertinya kurang diperhatikan oleh para perokok terutama perokok remaja dan anak-anak. Padahal merokok dapat menyebabkan kanker, serangan jantung, impotensi dan ganguan kehamilan dan janin seperti yang tertera pada bungkus rokok. Perilaku merokok juga diduga erat menyumbang secara signifikan 30\% kematian dari seluruh pengidap kanker, dan $87 \%$ kematian dari seluruh pengidap kanker paru-paru. Resiko untuk mengidap kanker dikemudian hari 23 kali lebih besar pada pria dan 13 kali lebih besar pada wanita dibandingkan dengan orang-orang yang tidak merokok. Kanker yang dapat muncul akibat merokok setidaknya ada 15 jenis, yaitu nasofaring, nasal cativy, bibir, oral cavity, faring, laring, paru-paru, esofagus, pankreas, mulut rahim, kidney, ginjal, lambung, dan kanker darah.

Bahaya merokok sudah banyak diketahui oleh masyarakat kita tidak terkecuali para perokok, namun jumlah perokok di Indonesia tidak mengalami penurunan bahkan selalu meningkat setiap tahunnya. Sekarang Indonesia sudah menduduki peringkat ketiga negara pengkonsumsi rokok di dunia. Diatas Indonesia ada China dan India. Beberapa tahun yang lalu perokok di Indonesia berjumlah 65 juta orang, tetapi sekarang sudah mendekati angka 100 juta orang (Ganyong, 2010). Selain meningkat dalam jumlah orangnya, usia perokok pun semakin lama semakin muda. Menurut data Komnas Anak, pada tahun 1970 usia perokok termuda adalah 15 tahun, namun pada tahun 2004 usia perokok termuda adalah 7 tahun (Messwati, 2008). Davidson, Neale, \& Kring (2006) menyatakan bahwa lebih dari 1000 anak dan remaja mulai merokok untuk pertama kalinya setiap hari, dan 750 orang diantaranya akan tewas diusia muda karena penyakit yang berhubungan dengan merokok yang sebenarnya dapat dicegah.

Semakin muda usia perokok, semakin dini dan semakin banyak pula zat-zat berbahaya dari hasil pembakaran rokok yang masuk ke tubuh perokok. Zat-zat tersebut tentulah berpengaruh negatif terhadap kesehatan dari perokok muda tersebut. Dengan demikian, semakin besar kemungkinan bagi perokok muda untuk menderita penyakit-penyakit yang disebabkan oleh rokok. Namun sepertinya hal ini kurang diperhatikan oleh perokok muda terutama anak-anak latechildhood yang memutuskan untuk merokok. Seseorang yang sudah tahu bahaya merokok tetapi tetap memutuskan untuk merokok atau mencoba merokok, tentu memiliki alasan tertentu. Alasan tersebut bisa sangat bervariasi tergantung individu yang bersangkutan, lingkungan dan faktor-faktor lainnya. Survey GLOBAL YOUTH TOBACCO tentang perokok usia sekolah 13-15 tahun menunjukkan, sebagian besar perokok muda Indonesia tertarik ikut merokok atas ajakan teman atau karena tergiur iklan rokok (Safitri, 2010). Sejalan dengan Survey Global Youth Tobacco, Komnas Perlindungan Anak juga melakukan penelitian yang menunjukkan bahwa 91,7 \% remaja berusia 13-15 tahun di DKI Jakarta merokok karena didorong oleh pengaruh iklan (Total Ban, 2009) . 
Penelitian oleh Komasari dan Helmi (dalam Komasari \& Helmi, 2000) menyatakan bahwa tiga faktor penyebab perilaku merokok pada remaja adalah kepuasan psikologis, sikap permisif orang tua terhadap perilaku merokok remaja, dan pengaruh teman sebaya. Donovan \& Jessor (1985) mengatakan bahwa $70 \%$ remaja merokok disebabkan oleh pengaruh teman. Penelitian oleh Wu \& Anthony (1999) menemukan bahwa seseorang yang berusia 8 - 9 sampai 13 - 14 tahun yang merokok mengalami peningkatan risiko sederhana terhadap mood depresi, tetapi mood depresi tidak berhubungan dengan peningkatan risiko bagi seseorang untuk memulai merokok. Merujuk pada data yang ada dapat disimpulkan bahwa remaja merokok disebabkan oleh kepuasan psikologis yang didapat dari perilaku merokok, sikap permisif orang tua, pengaruh teman sebaya dan pengaruh iklan.

Perilaku merokok pada remaja sudah sangat jelas faktor penyebabnya, namun yang menjadi pertanyaan adalah apa faktor penyebab perilaku merokok late childhood. Seperti yang diungkapkan oleh Soerojo, et. al. (2007), bahwa 3 dari 10 pelajar ditemukan merokok pertama kali sebelum mereka mencapai usia 10 tahun.

Penelitian ini dilakukan untuk mengetahui motif atau factor pendorong latechildhood merokok. Faktor apa saja yang melatarbelakangi perilaku merokok pada anak-anak mengingat usia late childhood masih terlalu muda untuk berkenalan dengan dunia rokok. Usia late childhood yang masih dibawah pengawasan orang tua, dianggap belum terlalu mengerti tentang bahaya dan efek negatif yang harus mereka tanggung dari perilaku merokok mereka. Penelitian ini juga dilakukan untuk mengetahui apakah yang melatarbelakangi perilaku merokok pada late childhood memiliki kemiripan dengan remaja, atau para late childhood memiliki alasan sendiri ketika mereka memutuskan untuk merokok.

\section{METODE}

Menjelaskan kronologis penelitian termasuk cara menyiapkan bahan penelitian, rancangan atau desain penelitian, prosedur penelitian (dalam bentuk algoritma, pseudocode atau lainnya), cara pengujian dan pengambilan data. Pada bagian ini boleh juga diberikan dasar teori. Tabel dan Gambar dibuat center seperti di bawah ini dan diacu pada naskah. Desain penelitian yang digunakan adalah desain penelitian kualitatif, studi kasus. Pengambilan data tentang motif dan latar belakang subjek merokok dilakukan melalui oservasi dan wawancara langsung yang mendalam Desain penelitian kualitatif atau yang biasa disebut juga sebagai case study method (metode studi kasus) memiliki beberapa karakteristik (Shaughnessy, Zechmeister, \& Zechmeister, 2009) :

Adapun definisi operasional motif atau faktor pendorong adalah suatu rangsangan atau dorongan dari dalam diri maupun luar diri yang mengarah pada terjadinya suatu perilaku. Sedangkan definisi operasional perilaku merokok adalah aktivitas membakar tembakau dan menghisap atau menghirup asap rokok dengan menggunakan pipa atau langsung dari rokoknya (disebut mainstream smoke), kemudian menghembuskan kembali asap tersebut ke udara (disebut sidestream smoke).

Jenis data penelitian ini adalah hasil wawancara yang diketik dalam bentuk verbatim sebagai data primer. Data sekunder berasal dari hasil observasi di lingkungan tempat tinggal dan lingkungan bermain subjek. Dalam penelitian ini, teknik wawancara dan observasi digunakan untuk mendapat data-data dari subjek tentang perilaku merokok yang mereka miliki. Menurut Chaplin (2006) yang dimaksud dengan wawancara adalah suatu percakapan tatap muka, dimana salah satu tujuannya untuk memperoleh informasi faktual. Observasi adalah suatu pengujian dengan maksud atau tujuan tertentu, khususnya untuk mengumpulkan data.

Teknik wawancara dilakukan dua kali pada masing-masing partisipan dan satu kali pada ayah dari masing-masing partisipan. Wawancara yang dilakukan pada ayah partisipan bertujuan untuk mengetahui apakah ada pengaruh faktor keluarga pada perilaku merokok partisipan. Teknik obeservasi 
dilakukan dengan tujuan mengetahui kondisi lingkungan tempat tinggal dan tempat bermain partisipan sebagai data pendukung pada penelitian ini.

Pengambilan sampel dalam penelitian ini menggunakan teknik non probability sampling dengan spesifikasi purposive sampling. Purposive sampling adalah teknik pengambilan sampel sumber data dengan pertimbangan tertentu (Sugiyono, 2009). Pertimbangan tertentu yang dimaksud bisa disesuaikan dengan tujuan penelitian. Tujuan penelitian ini adalah untuk mengetahui motif atau faktor pendorong perilaku merokok pada late childhood. Untuk itu pemilihan subjek adalah late childhood yang merokok atau pernah merokok. Subjek berada pada kirasan usia 6 sampai 11 tahun, berjenis kelamin laki - laki, dan memiliki atau pernah memiliki perilaku merokok. Jumlah partisipan yang dibutuhkan adalah 3 orang anak late childhood laki-laki yang merokok atau pernah setiap hari. Tidak ada batasan berapa jumlah rokok yang dihabiskan dalam sehari oleh partisipan. Subjek penelitian yang memenuhi criteria yang ditentukan adalah tiga orang. Data ketiga orang subjek tersebut diharapkan dapat menggambarkan keragaman motif yang mendasari perilaku merokok pada anak late childhood.

Hasil wawancara dibuat verbatim. Setelah diperoleh gambaran umum dari ketiga subjek kemudian dikoding dan dikatagorisasi berdasarkan factor-faktor pendorong sebagai motif merokok dari ketiga subjek. Setelah penkodingan dan katagorisasi, faktor-faktor apa yang muncul sebagai pendorong perilaku merokok pada ketiga subjek dianalisa berdasarkan landasan teori yang terkait.

\section{HASIL DAN PEMBAHASAN}

\section{Data Hasil}

\section{Profil Subjek}

Subjek penelitian ini adalah 3 orang late childhood yang bertempat tinggal di Jakarta Barat. Teknik pengambilan data adalah dengan wawancara dan observasi. Wawancara dilakukan masingmasing 2 kali pada setiap partisipan dan masing-masing 1 kali pada ayah subjek. Wawancara pada partisipan 1 dilakukan tanggal 5 November 2010 dan dan 30 November 2010. Subjek 2 dan 3 diwawancara pada tanggal 30 November dan 30 Desember 2010. Wawancara pertama pada subjek 2 dan 3 dilakukan dalam waktu yang bersamaan. Ketika interviewer menanyakan sebuah pertanyaan, subjek 2 dan 3 bergiliran menjawab. Wawancara kedua pada subjek 2 dan 3 dilakukan pada waktu yang bersamaan pula, namun dengan sistem bergiliran. Subjek 3 terlebihdahulu diwawancara sampai selesai, kemudian bergantian subjek 2 yang diwawancara. Wawancara pada ayah dari subjek pertama dilakukan pada tanggal 14 Desember 2010. Wawancara pada ayah dari subjek ke 3 dilakukan pada tanggal 8 Januari 20111. Wawancara pada ayah dari subjek ke 2 dilakukan pada tanggal 17 Januari 2011.

Selain wawancara, dilakukan observasi pada lingkungan tempat tinggal serta lingkungan bermain subjek. Hal ini dilakukan untuk memperkaya informasi tentang subjek serta menggali lebih jauh faktor-faktor apa yang menjadi pendorong perilaku merokok pada ketiga subjek.

Berikut di bawah ini diuraikan profil dari subjek yang terlibat dalam penelitian: 
Tabel 1 Profil Subjek Penelitian

\begin{tabular}{lccc}
\hline \multicolumn{1}{c}{ Item } & Subjek 1 & Subjek 2 & Subjek 3 \\
\hline inisial nama & $\mathrm{R}$ & $\mathrm{Y}$ & $\mathrm{D}$ \\
Usia & 11 & 11 & 11 \\
$\begin{array}{l}\text { Pendidikan } \\
\text { penghasilan keluarga }\end{array}$ & SD Kelas 5 & SD kelas 5 & SD kelas 5 \\
jumlah anggota kel. & \pm 1.000 .000 & \pm 1.600 .000 & \pm 1.800 .000 \\
kel. yg merokok & 4 orang & 5 orang & 4 orang \\
tahapan merokok & ayah dan kakak & ayah dan kakak & Ayah \\
ketergantungan (DSM-IV) & Initiation & Initiation & Initiation \\
\hline
\end{tabular}

Tabel di atas menjelaskan bahwa ketiga subjek berada pada usia yang sama serta latar belakang pendidikan yang sama. Ketiga subjek juga memiliki anggota keluarga yang merokok. Hal tersebut sangat memungkinkan subjek untuk mencontoh perilaku merokok anggota keluarganya.

Tahapan merokok yang dimiliki subjek menurut Leventhal dan Clearly (dalam Komasari \& Helmi, 2000) berada pada tahap Initiation (perintisan) yang berarti pada tahap ini individu yang bersangkutan sedang mempertimbangkan apakah akan meneruskan atau tidak perilaku merokoknya. Subjek D dan Y telah memutuskan untuk menghentikan perilaku merokok mereka. Subjek R memutuskan untuk meneruskan perilaku merokoknya, namun $\mathrm{R}$ tidak dapat dikategorikan sebagai becoming a smoker karena jumlah rokok yang dihabiskan dalam 1 hari tidak sampai empat batang. Ketiga subjek juga tidak mengalami ketergantungan terhadap rokok karena tidak memenuhi satu pun kriteria yang ditentukan dalam DSM-IV.

\section{Latar Belakang Subjek}

\section{Subjek R}

R merupakan anak ke-2 dari 2 bersaudara. Kedua orang tua $\mathrm{R}$ masih hidup. $\mathrm{R}$ lahir di Jakarta, dan menetap di Jakarta. R lahir pada tahun 1999, jadi usianya sekarang 11 tahun. Beda usia dengan kakaknya adalah 8 tahun. Usia ayahnya 43 tahun, sedangkan ibunya 40 tahun. Ayahnya dulu berprofesi sebagai supir angkot, tetapi beberapa bulan terakhir sedang tidak bekerja. Sedangkan ibunya adalah ibu rumah tangga. Kakak R bekerja sebagai officeboy pada salah satu supermarket di Jakarta. Ayah R yang sedang tidak bekerja menyebabkan pemenuhan kebutuhan keluarga $\mathrm{R}$ hanya tergantung pada penghasilan dari kakak R. Penghasilan kakak R sendiri sekitar satu juta rupiah setiap bulannya. Hal ini menyebabkan keluarga $\mathrm{R}$ harus sangat berhemat agar penghasilan kakak $\mathrm{R}$ cukup untuk memenuhi kebutuhan keluarga selama 1 bulan sampai ayah $\mathrm{R}$ mendapatkan pekerjaan lagi.

$\mathrm{R}$ berasal dari keluarga dengan status ekonomi mengengah ke bawah. Hal ini terlihat dari penghasilan kakak $\mathrm{R}$ yang saat ini menjadi tulang punggung keluarga tidak lebih dari UMR yang ditentukan oleh pemerintah. UMR yang ditentukan pemerintah adalah sebesar 1.290.000 rupiah untuk daerah DKI Jakarta tahun 2011 (Purwoko, 2010). Selain itu, rumah R cukup kecil untuk ditinggali sebuah keluarga beranggotakan 4 orang. Rumah R hanya terdiri dari 2 ruangan, ruang depan yang sekaligus berfungsi sebagai ruang tamu, ruang keluarga dan kamar tidur. Sedangkan di ruang belakang terdapat dapur dan kamar mandi. Rumah $\mathrm{R}$ berada di gang kecil yang hanya cukup dilewati sebuah motor.

Kegiatan sehari-harinya adalah sekolah di SD Grogol Utara 05 pagi, duduk di kelas 5 SD. Sepulang sekolah, R biasanya pulang ke rumah untuk makan siang dan ganti baju. Setelah itu, R biasanya main ke warnet bersama teman-temannya. $R$ biasa bermain 1 sampai 2 jam sehari di warnet. 
Jika sedang tidak bermain ke warnet, R biasanya bermain sepak bola bersama teman-temannya. Sejak kelas 4 awal, timbul ketertarikan untuk merokok pada diri $\mathrm{R}$ dikarenakan bujukan teman-teman sepermainan $\mathrm{R}$ di warnet. $\mathrm{R}$ biasa mengkonsumsi rokok merk Mild.

\section{Subjek Y}

Y merupakan anak kedua dari 3 bersaudara. Y memiliki seorang kakak berusia 22 tahun dan seorang adik yang berumur 10 tahunan. Ayah D berprofesi sebagai satpam di daerah Kebon Nanas (Kebayoran Lama), sedangkan ibu D adalah ibu rumah tangga. Ayah Y berusia 44 tahun ibu Y berusia 40 tahunan. Y lahir di Jakarta pada tahun 1999. Tulang punggung keluarga di keluarga Y adalah ayah dan kakaknya. Profesi ayahnya sebagai satpam memberi penghasilan dibawah satu juta rupiah setiap bulannya, sedangkan kakaknya yang berprofesi sebagai karyawan pada sebuah tempat makan memperoleh penghasilan sekitar enam ratus ribu rupiah per bulannya.

Penghasilan kakak dan ayah Y yang berada di bawah UMR menunjukkan bahwa keluarga tersebut berada pada taraf hidup yang kurang layak. Selain itu, rumah Y yang terletak di Kebayoran Lama tidaklah terlalu besar. Hanya memiliki satu buah ruang tamu yang merangkap sebagai ruang keluarga dan ruang makan. Sebuah kamar yang ditiduri oleh 5 orang dan sebuah dapur serta 1 buah kamar mandi. Rumah Y pun berada di gang kecil yang hanya cukup dilewati 1 buah motor. Hal ini ikut menunjukkan bahwa keluarga Y berada pada status ekonomi menengah kebawah.

Kegiatan sehari-hari Y adalah sekolah pada pagi hingga siang hari. Usai sekolah, Y pulang kerumah untuk makan siang dan ganti baju. Setelah itu, Y biasa main ke warnet bersama temantemannya. Di warnet Y biasa bermain game online Point Blank. Y merokok sejak kelas 3 SD. Y biasanya merokok di lingkungan warnet bersama teman-teman sepermainannya. Merek rokok yang di konsumsi Y adalah Djarum Super. Namun, saat ini Y telah berhenti merokok dikarenakan pernah mengalami sakit pada bagian dada. Y takut jika sakit tersebut disebabkan oleh perilaku merokoknya.

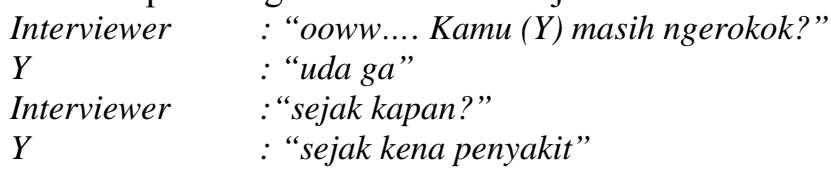

Merujuk pada hasil wawancara diatas, dapat disimpulkan bahwa Y mampu menghubungkan penyakit yang dideritanya dengan perilaku merokoknya. Hal ini sesuai dengan pernyataan Piaget dalam (Santrock, 2007a) yang mengatakan bahwa perkembangan kognitif pada anak late childhood memampukan anak untuk berpikir logis tentang hal-hal konkret. Kemampuan Y untuk menghubungkan sakit di bagian dadanya dengan perilaku merokoknya menunjukkan bahwa Y mampu berpikir logis tentang 2 hal konkret tersebut.

\section{Subjek D}

$\mathrm{D}$ adalah anak pertama dari 2 bersaudara. $\mathrm{D}$ memiliki seorang adik perempuan yang berumur 10 tahun. Ayah D berprofesi sebagai supir pribadi, sedangkan ibu D adalah seorang cleaning service. Ayah D berusia 34 tahun dan ibu D berusia 32 tahun. D lahir di Jakarta pada tahun 1999. Penghasilan ayahnya sekitar satu juta per bulannya, dan penghasilan ibunya berkisar delapan ratus ribu per bulan. penghasilan kedua orang tuanya berada di bawah UMR yang menyebabkan keluarga D termasuk kategori sosial ekomoni menengah kebawah.

D tinggal di daerah Kebayoran Lama bersama kedua orang tua dan seorang adiknya. Rumah D terletak di gang kecil dengan sebuah ruang tamu yang merangkap ruang makan tanpa meja. Rumah D hanya memiliki 1 buah kamar yang ditempati 4 orang, sebuah dapur kecil yang luasnya tidak lebih dari $2 \times 1$ meter dan sebuah kamar mandi. 
Kegiatan sehari-hari D adalah sekolah pada pagi hingga siang hari. Usai sekolah, D pulang kerumah untuk makan siang dan ganti baju. Setelah itu, D biasa main ke warnet bersama temantemannya. Di warnet D biasa bermain game online Point Blank. D merokok sejak kelas 4 SD. D biasanya merokok di lingkungan warnet bersama teman-teman sepermainannya. Merk rokok yang di konsumsi D adalah Mild. Namun, sekarang D telah berhenti merokok dikarenakan takut terkena penyakit kanker yang dapat ditimbulkan dari rokok.
$D$
: "ga, satu doank.. takut kena penyakit kanker"
Interviewer
: "hahh? Takut? Kok ga berhenti aja kalo takut?"
$D$
: "sekarang uda berhenti

\section{Pembahasan}

Setelah dilakukan wawancara pada ketiga subjek dan masing-masing ayahnya, diperoleh beberapa fakta mengenai faktor pendorong perilaku merokok yang terjadi pada ketiga partisipan tersebut. Faktor pendorong tersebut akan dijelaskan satu persatu beserta cuplikan hasil wawancara sebagai bahan pendukung.

\section{Faktor Teman}

Perilaku merokok pada ketiga subjek muncul dikarenakan teman sebagai faktor utamanya. Teman-teman sepermainan yang kebanyakan merokok sering menawari ketiga subjek untuk mencoba rokok. Rasa ingin tahu yang tinggi, ditambah tawaran berulang kali dari teman pada akhirnya memunculkan perilaku merokok pada 3 anak late childhood ini.
Interviewer : "ngerokok ditawarin temen apa pengen nyoba sendiri?”
$R \quad$ : "ditawarin"
Interviewer : "yang ngajakin R juga?”
D : "katanya cobain aja.."
Interviewer : "berarti pertama kali ngerokok diajakin A?"
Y $\quad:$ (mengangguk)

Selain mengajak mereka merokok, teman-teman subjek pun mengajari mereka merokok dengan menjadi role model untuk mereka. Subjek kemudian mengikuti teknik-teknik merokok yang dicontohkan oleh teman-temannya.
Interviewer : "belajar merokok dari siapa dulu?"
$R \quad$ : "ngeliat"
Interviewer : "panutan ngerokoknya siapa?”
$D \quad:$ : $R$ "
Interviewer : "nyontohin siapa dulu ngerokoknya?”
$Y \quad$ : "A sama $R$ ”

Hal ini dapat dijelaskan dengan menggunakan teori modeling dari Albert Bandura. Bandura (dalam Santrock, 2007b) mengatakan bahwa pembelajaran modeling terjadi ketika seseorang mengamati dan meniru perilaku orang lain. Dengan meniru perilaku merokok dari teman-temannya, ketiga subjek akhirnya memiliki kemampuan untuk merokok meskipun pada awalnya subjek D dan Y mengalami batuk-batuk ketika mencoba merokok.
Interviewer
: "waktu awal ngerokok gimana rasanya? Batuk-batuk ga?”
$D$
Interviewer
: "pernah sih batuk-batuk... eh.. keterusan-keterusan kaga..."
$Y$
: "habis itu? Langsung bisa? Apa batuk-batuk?”
: "pertama pas mau narik, batuk... dah lama-lama eh bisa.."

Pengaruh teman memang merupakan faktor pendorong yang sangat kuat bagi perilaku merokok ketiga subjek, terutama pada subjek R. R sampai saat ini belum berhenti merokok, sedangkan $\mathrm{D}$ dan $\mathrm{Y}$ sudah berhenti merokok. Hal ini mungkin disebabkan oleh pengaruh teman-teman sepermainan R. Menurut pengakuan D dan Y, R sekarang sering bergaul dengan teman-teman barunya yang terdiri dari anak-anak punk. Ketika bergaul dengan anak punk, $\mathrm{R}$ bukan hanya mempertahankan 
perilaku merokoknya, namun $\mathrm{R}$ juga pernah mencoba obat-obat yang berjenis halusinogen. Fungsi halusinogen adalah menimbulkan halusinasi pada diri subjek yang menggunakannya (Davidson, Neale, \& Kring, 2006). Perbedaan teman sepermainan sangat mungkin menyebabkan perbedaan keputusan tentang merokok yang dibuat oleh ketiga partisipan.

\section{Faktor Pribadi}

Faktor pribadi yang berhasil digali dalam penelitian ini adalah rasa ingin tahu dan persepsi terlihat lebih menarik karena merokok.

Awalnya ketiga partisipan tersebut memutuskan merokok karena rasa ingin tahu yang tinggi terhadap rokok.

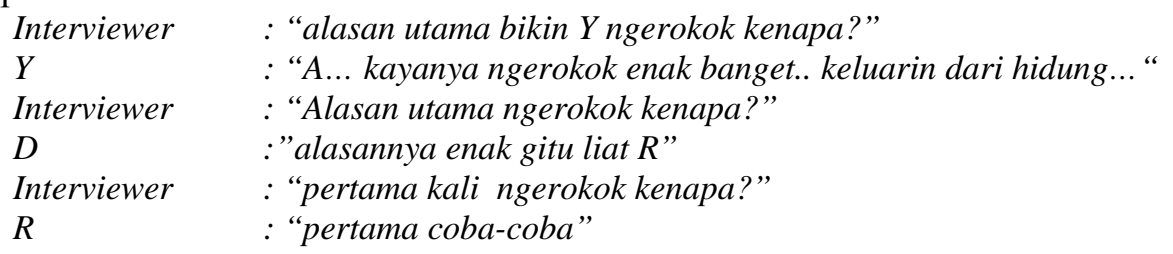

Rasa ingin tahu tersebut muncul setelah partisipan berulang kali memperhatikan temantemannya merokok. Ekspresi yang muncul dari teman-teman yang merokok pada akhirnya menarik rasa ingin tahu yang tinggi dari ketiga partisipan tersebut. Akhirnya ketiga partisipan tersebut memutuskan untuk mencoba merokok. Rasa ingin tahu yang tinggi pada masa late childhood memang tidak mengherankan karena rasa ingin tahu sudah menjadi ciri khas dari masa kanak-kanak. Eric Ericson (dalam Santrock, 2008) mengatakan bahwa anak pada tahap middle dan late childhood anak senang mencoba hal-hal baru terutama pengetahuan dan skills baru. Pengetahuan dan skills baru tersebut yang membantu anak belajar lebih banyak tentang lingkungannya, begitupun dengan perilaku merokok mereka. Rasa ingin tahu yang tinggi pada rokok dikarenakan mereka hanya tahu rokok dari bentuk luarnya saja, tetapi tidak pernah tahu bagaimana rasanya merokok. Hal ini mendorong ketiga partisipan untuk mencoba rokok guna memenuhi rasa ingin tahu mereka.

Rasa ingin tahu yang tinggi terhadap rokok memang merupakan alasan yang cukup berpengaruh bagi ketiga subjek mencoba rokok, tetapi ada alasan lain yang muncul dari subjek ketika memutuskan untuk melanjutkan perilaku merokoknya. Alasan tersebut adalah ingin terlihat keren atau menarik dengan perilaku merokok.

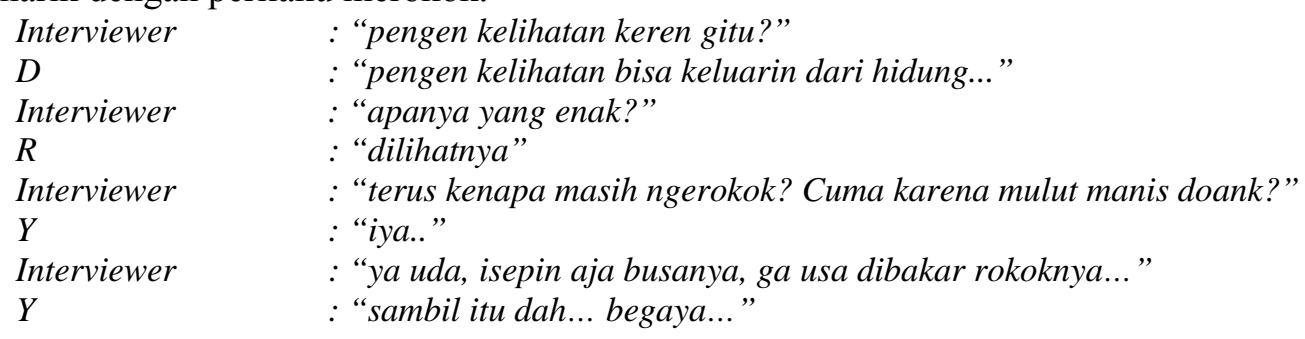

Kesan keren atau menarik yang dimunculkan dari rokok dianggap menambah kepercayaan diri mereka. Hal ini sesuai dengan perkembangan psikososial menurut Eric Erikson (dalam Santrock, 2008) yang mengatakan bahwa anak middle dan late childhood berada pada tahap perkembangan industry versus inveriority. Anak tergolong industry ketika dia kompeten melakukan sesuatu, dan dia dianggap inveriority ketika sang anak tidak kompeten dalam hal tertentu. Dikaitkan dengan hasil penelitian, dapat dijelaskan bahwa ketiga partisipan kompeten dalam perilaku merokok mereka terbukti dari kemampuan mereka untuk merokok tanpa mengalami hambatan berarti. Kompetensi mereka dalam perilaku merokoknya membuat mereka terlihat menarik. Dengan terlihat menarik, ketiga partisipan merasa lebih percaya diri. Kepercayaan diri yang cukup memampukan mereka untuk bergaul dan menjadi bagian dari komunitas tempat mereka biasa bermain. 


\section{Faktor Keluarga}

Temuan yang diperoleh dari penelitian ini adalah bahwa factor keluarga turut berkontribusi dalam mendorong ketiga subjek merokok. Sosok ayah, sebagai model yang signifikan bagi ketiga contoh untuk melakukan proses modelling.

$\mathrm{R}, \mathrm{D}$, dan $\mathrm{Y}$ lahir dari keluarga yang tidak menganggap rokok sebagai sesuatu hal yang buruk. Ayah dan kakak mereka merupakan perokok.

$\begin{array}{ll}\text { Interviewer } & : \text { "ayah ngerokok ga? } \\ R & : \text { "engga... eh, ngerokok } \\ \text { Interviewer } & : \text { "terus kakaknya ngerokok?” } \\ R & : \text { "ngerokok" } \\ \text { Interviewer } & : \text { "bapak ngerokok ga?" } \\ D & : \text { "ngerokok" } \\ Y & : \text { "ngerokok" }\end{array}$

Kebiasaan merokok ayah mereka pun dimulai sejak kecil, tidak mengherankan keluarga mereka cukup akrab dengan rokok.

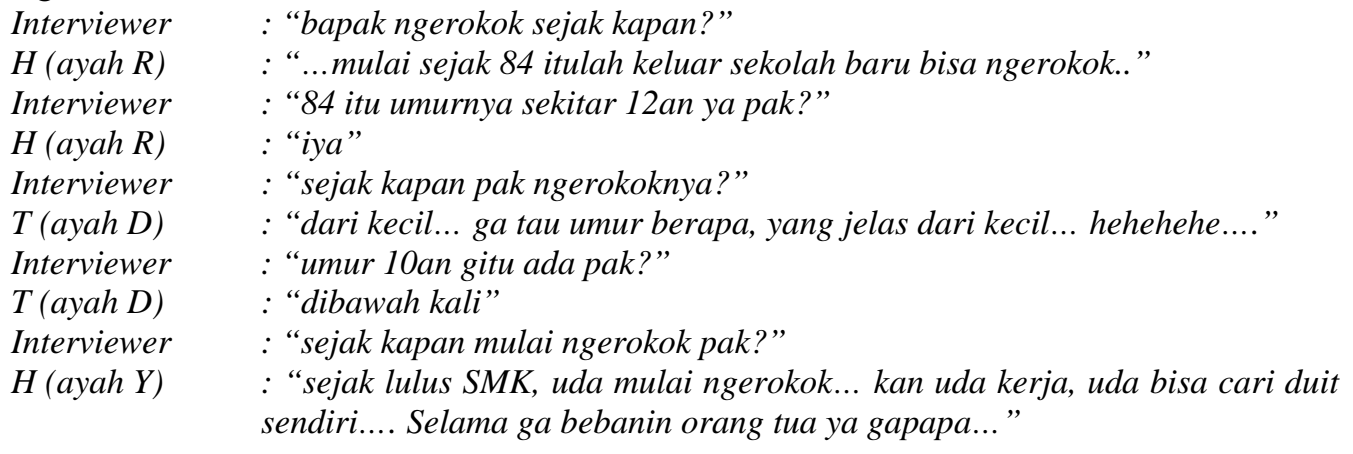

Kebiasaan merokok sejak kecil tersebut mereka bawa hingga sekarang. Merokok sudah seperti kebutuhan sehari-hari untuk mereka dan tidak dianggap sebagai hal yang buruk. Merokok yang telah menjadi kebutuhan sehari-hari pada akhirnya mempunyai efek tersendiri bagi mereka.

\begin{tabular}{|c|c|}
\hline Interviewer & $\begin{array}{l}\text { : "bapak ngerasa ga kalau rokok itu bikin kecanduan karena nikotinnya? Zat } \\
\text { adiktif gitu-gitu... pada akhirnya itu ga sih yang bikin orang pengen rokok, } \\
\text { pengen rokok, pengen rokok dan jumlahnya nambah terus qitu..." }\end{array}$ \\
\hline$H($ ayah $R)$ & $\begin{array}{l}\text { :"kadang-kadang bukan dari itu aja sih ya.. dari segi otak juga... pemikiran- } \\
\text { pemikiran.... Karena dengan adanya itu, pikiran kita ga terlalu tinggi gitu.... } \\
\text { Dibawa santai... menurunkan kadar untuk berpikir tinggi gitu.." }\end{array}$ \\
\hline Interviewer & : “ooww.... Terus kalo positifnya apa pak?” \\
\hline$H($ ayah $Y)$ & $\begin{array}{l}\text { : "yah itu... kalo lagi ngelamun, ada yang dipikirin jadi enak.. bisa ketemu } \\
\text { jalan keluar... terus kalo lagi kerja, ga berasa tau-tau uda selesai aja..." }\end{array}$ \\
\hline & : “kalau positifnya kira-kira apa yang bapak rasa dari merokok?” \\
\hline$T($ ayah D) & $\begin{array}{l}\text { : "kalau positif ga ada... Cuma ya begini aja, ga terlalu digimana gitu kan... } \\
\text { yang jelas buat saya ya harus ada rokok gitu aja.. kalau masih mampu beli... }\end{array}$ \\
\hline
\end{tabular}

Pengakuan orang tua $\mathrm{R}$ dan $\mathrm{Y}$ menunjukkan bahwa mereka mendapatkan dampak positif dari merokok. Dampak positif ditandai dengan adanya mood positif setelah merokok dan rokok dianggap membantu individu menghadapi keadaan-keadaan yang sulit (Ogden, 2000). Menurut Leventhal \& Clearly (dalam Komasari \& Helmi, 2000) orang tua R dan Y telah memasuki tahap maintenance a smoking dalam tahapan menjadi perokok. Pada tahap ini merokok dilakukan untuk memperoleh efek psikologis yang menyenangkan. Hal yang berbeda terjadi pada orang tua D. Pengakuan yang beliau lontarkan menunjukkan bahwa beliau tidak memperoleh efek psikologis dari perilaku merokok. Hal ini berarti beliau hanya sampai pada tahap becoming a smoker. Tahap becoming a smoker berarti orang yang bersangkutan telah mengkonsumsi rokok sebanyak empat batang perhari. 
Merujuk pada tahapan-tahapan merokok yang dimiliki orang tua subjek, dapat dilihat bahwa rokok sangatlah dekat dengan hidup mereka. Rokok cenderung memiliki efek positif bagi mereka, dan mereka tidak dapat menghilangkan perilaku merokok mereka. Oleh karena itu, mereka pun tidak segan-segan merokok di depan anak-anak mereka meskipun perilaku merokok mereka sangat mungkin untuk dicontoh oleh anak-anak mereka.

\begin{tabular}{|c|c|}
\hline Interviewer & $\begin{array}{l}\text { : "tapi bapak ngerokoknya ga pernah ngumpet-ngumpet di belakang anak- } \\
\text { anak?" }\end{array}$ \\
\hline$H($ ayah $R)$ & $\begin{array}{l}\text { : ‘saya ga... dari dulu juga waktu dia (R) belum lahir, saya uda ngerokok, ga } \\
\text { pake ngumpet-ngumpet itu... ga perlu... karena saya pikir sejarahnya ga ada } \\
\text { dari rokok gitu...” }\end{array}$ \\
\hline Intervi & : “kalau ngerokok ga pernah dibelakang anak-anak kan pak ya?” \\
\hline$T($ ayah $D)$ & 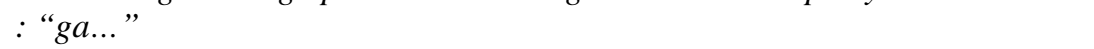 \\
\hline \multicolumn{2}{|c|}{$\begin{array}{l}\text { Interviewer: “ooww.... Bapak ngerokok di depan anak-anak ga pak?” } \\
\text { H } \quad \text { "yah kalo kebetulan ada mereka aia kalau ag ada va mereka aa liat _ " }\end{array}$} \\
\hline & : "yah kalo kebetulan ada mereka aja, kalau ga ada ya mereka ga liat ... " \\
\hline
\end{tabular}

Kebiasaan merokok di depan anak-anak juga dapat memunculkan rasa ingin tahu pada diri anak yang bersangkutan selain karena teman-teman partisipan yang rata-rata adalah perokok. Hal ini sejalan dengan pernyataan Mu'tadin (dalam Nasution, 2007) yang mengatakan bahwa orang tua yang merokok bisa menjadi contoh paling kuat untuk anak dalam memutuskan untuk merokok. Setelah muncul rasa ingin tahu, anak-anak mencoba-coba untuk merokok dimana lingkungan bermain juga ikut mendukung. Dengan demikian, anak telah belajar menjadi seorang perokok.

Pola asuh orang tua terhadap anak, pada akhirnya akan menentukan bagaimana anak tersebut mengambil keputusan untuk hidupnya. Jika dilihat dari hasil wawancara dan observasi terhadap anak dan orang tua partisipan, dapat dilihat bahwa orang tua partisipan cenderung memilih neglectful parenting, dimana orang tua tidak terlibat aktif dalam kehidupan anaknya. Anak-anak dari orang tua yang neglectful cenderung kurang bisa mengontrol diri, tidak cukup mandiri, dan tidak termotivasi untuk berprestasi (Santrock, 2007).

Hal ini terlihat dalam pembicaraan ringan dengan D dan Y setelah wawancara selesai. Saat itu sudah jam 8 malam, dan D belum makan malam.
Interviewer
: "kok belum makan?”,
D : "ayah dan ibu belum pulang".
Interviewer : "terus mau makan jam berapa?",
D $\quad$ : "tau dah.. tunggu ayah atau ibu pulang dah."

Hal itu merupakan salah satu contoh orang tua yang neglect karena tidak mampu memenuhi kebutuhan fisiologis anaknya dengan baik. Selain contoh diatas, dalam observasi yang dilakukan peneliti terlihat bahwa orang tua dari masing-masing partisipan cenderung tidak mengkhawatirkan anak-anak mereka yang pulang diatas jam 9 malam. Biasanya ketiga subjek sering bermain di warnet hingga jam 9 malam. Sesudah itu, ketiga subjek pulang kerumah masing-masing dengan berjalan kaki. Pada Sabtu malam, ketiga subjek akan bermalam di warnet untuk bermain paket gadang. Mereka kemudian berbohong pada orang tua mereka dengan mengatakan menginap di rumah teman mereka.

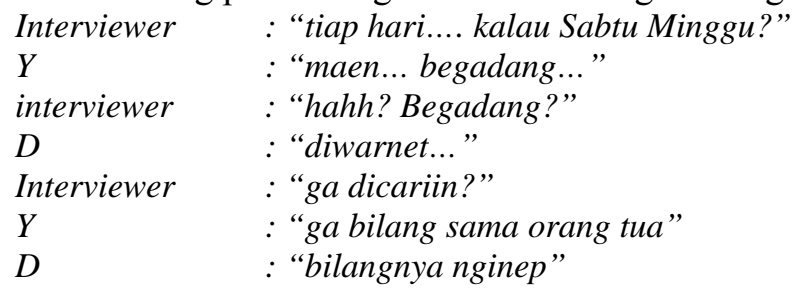

Pernyataan ketiga subjek di atas turut menunjukkan bahwa orang tua dari ketiga subjek cenderung tidak mengkhawatirkan anaknya dan tidak berusaha mencari tahu apakah anak-anak mereka benar-benar menginap dirumah temannya. Hal ini menunjukkan bahwa orang tua dari ketiga subjek menganut paham neglectful parenting dalam pengasuhan anak-anaknya. 
Selain pola asuh yang bersifat neglect, orang tua dari ketiga subjek juga memiliki pola asuh permisif, dimana orang tua cenderung tidak terlalu banyak menerapkan aturan baku dalam mendidik anak-anaknya. Hal ini terlihat dari pengakuan dari ayah ketiga partisipan yang mengatakan tidak melarang perilaku merokok anak-anaknya.

\begin{tabular}{|c|c|}
\hline Interviewer & : "berarti bapak tidak melarang bapaknya R merokok ya?” \\
\hline$H($ ayah $R)$ & : "he eh (iya)...” \\
\hline Interviewer & : "kalau tau-tau nanti anak-anak ngerokok gitu, bapak keberatan ga? \\
\hline$T$ & $\begin{array}{l}\text { : "kalau bisa ya jangan... daripada... percuma neng, misalkan kaya saya } \\
\text { ngerokok sembunyi-sembunyi gitu... kalau mau ngerokok ya ngerokok } \\
\text { aja..." }\end{array}$ \\
\hline $\begin{array}{l}\text { Interviewer } \\
\mathrm{H}\end{array}$ & $\begin{array}{l}\text { " "pernah ngelarang anak-anak ngerokok ga pak?” } \\
\text { " "ga pernah sih... paling bilangin jangan ngerokok aja.. entar kalo uda } \\
\text { kerja, uda bisa cari duit baru... Daripada minta duit buat rokok, ya } \\
\text { mending minta rokoknya sama saya sebatang dua batang... saya tungguin } \\
\text { ngerokoknya..." }\end{array}$ \\
\hline
\end{tabular}

Orang tua yang cenderung tidak melarang perilaku merokok anak-anaknya, membuat anak merasa bahwa rokok bukanlah sesuatu hal yang buruk. Ditambah dengan statement dari orang tua bahwa anak-anak boleh merokok jika sudah cukup umur dan sudah bekerja, semakin membuat ketiga partisipan merasa rokok sesuatu yang layak dicoba karena hanya orang-orang besar yang boleh merokok. Maka, dengan ketiga subjek merokok, mereka bisa terlihat seperti orang besar. Hal ini terlihat dari istilah "begaya" yang diungkapkan partisipan Y dalam wawancara.

Y : "sambil itu dah... begaya..."

\section{Faktor Iklan Rokok}

Iklan rokok juga merupakan faktor yang tidak bisa dipisahkan dari perilaku merokok pada 3 anak late childhood ini. Iklan rokok yang tersebar disegala media promosi seperti iklan TV, spandukspanduk dan poster-poster merupakan salah satu pemicu perilaku merokok pada ketiga subjek.
Interviewer
Y
: "ooww... habis ngeliat iklan rokok rasanya gimana?"
Interviewer
: "rasanya mau beli.."
$D$
Interviewer
: "waktu liat iklan rokok rasanya gimana?"
: "biasa aja... kadang pengen rokok, beli ah... gitu..."
$R$
: "kalau lagi liat iklan rokok rasanya gimana?”
: "langsung ke Kebon Nanas, ngerokok..."

LSM Komnas Perlindungan Anak pernah melakukan survei yang dilakukan di Jakarta pada anak-anak remaja. Hasilnya adalah 91.7 \% remaja berusia 13-15 tahun merokok dikarenakan pengaruh iklan (Total Ban, 2009). Fakta ini menunjukkan bahwa bagi remaja berusia 13-15 tahun, iklan merupakan faktor pendorong signifikan untuk merokok. Sebaliknya pada ketiga partisipan, iklan tidak memberi pengaruh yang signifikan pada perilaku merokok mereka. Iklan rokok tidak menjadi pemicu perilaku merokok pada partisipan, hanya saja iklan rokok terkadang memunculkan keinginan untuk merokok pada diri partisipan.

\section{Analisa}

Faktor pendorong perilaku merokok pada ketiga subjek terdiri dari faktor teman, faktor pribadi, pengaruh keluarga dan pengaruh iklan. Kesemua faktor tersebut saling terkait ketika memunculkan perilaku merokok pada ketiga partisipan, tidak ada faktor yang berdiri sendiri-sendiri. Penjelasan yang lebih lengkap akan dijelaskan melalui dua buah tabel dibawah ini. 
Tabel 2 Faktor Pendorong Perilaku Merokok pada Late childhood

\begin{tabular}{ccccc}
\hline & \multicolumn{4}{c}{ Faktor Pendorong Perilaku Merokok pada Late childhood } \\
\cline { 2 - 5 } partisipan & Pengaruh teman & Faktor Pribadi & Pengaruh keluarga & Faktor Iklan \\
R & $\sqrt{ }$ & $\sqrt{ }$ & $\sqrt{ }$ & $\sqrt{ }$ \\
D & $\sqrt{ }$ & $\sqrt{ }$ & $\sqrt{ }$ & $\sqrt{ }$ \\
Y & $\sqrt{ }$ & $\sqrt{ }$ & $\sqrt{ }$ & $\sqrt{ }$ \\
\hline
\end{tabular}

Tabel diatas menunjukkan bahwa ketiga subjek memiliki faktor pendorong yang sama dalam hal merokok. Faktor pendorong pertama adalah pengaruh teman. Teman-teman yang merokok serta sering menawari mereka merokok, membuat ketiga partisipan tersebut memutuskan untuk merokok. Selain menawari merokok, teman-teman subjek juga ikut menjadi role model bagi perilaku merokok ketiga partisipan. Teman-teman sepermainan yang memiliki peran dan pengaruh cukup besar pada akhirnya menjadi faktor pendorong utama yang memunculkan perilaku merokok pada ketiga partisipan. Hal ini tidak mengherankan karena pada masa late childhood, significant person untuk mereka adalah teman mereka (Papalia, Olds, \& Feldman, 2007). Dengan merokok bersama temantemannya, ketiga partisipan merasa diakui sebagai bagian dari kelompok atau komunitas tempat mereka bermain.

Faktor terpenting kedua adalah faktor pribadi dimana ketiga subjek memiliki rasa ingin tahu yang cukup tinggi terhadap hal-hal baru yang belum pernah mereka lihat atau rasakan. Hal ini didukung oleh teori Eric Erikson (dalam Santrock, 2008) yang mengatakan bahwa anak middle dan late childhood senang mencoba hal-hal baru terutama pengetahuan dan skills baru. Rasa ingin tahu yang tinggi, ditambah dorongan dari teman-teman pada akhirnya membuat ketiga subjek berani memutuskan untuk mencoba merokok.

Selain rasa ingin tahu yang tinggi, faktor pribadi lain yang ikut menjadi pendorong perilaku merokok pada ketiga partisipan adalah ingin terlihat menarik. Merokok membuat ketiga subjek terlihat menarik. Dengan terlihat menarik, subjek akhirnya mendapat peningkatan kepercayaan diri mereka. Dengan kepercayaan diri yang cukup, ketiga subjek mampu bergaul dan berinteraksi secara normal dengan lingkungan bermainnya.

Pengaruh teman dan pribadi subjek memang memegang peran penting dalam keputusan merokok yang diambil partisipan, namun pengaruh keluarga dan pola asuh merupakan faktor pendorong yang tidak bisa diremehkan. Orang tua yang merokok menjadi contoh yang sangat kuat bagi anak-anaknya untuk ikut merokok. Kebiasaan merokok setiap hari di depan anak-anak, membuat anak-anak memiliki persepsi bahwa rokok bukanlah hal yang buruk karena keluarganya merokok dan tidak pernah secara sembunyi-sembunyi. Dengan demikian, orang tua pun ikut menjadi role model bagi perilaku merokok pada ketiga partisipan tersebut. Hal ini sesuai dengan penjelasan tentang modeling dari Albert Bandura yang mengatakan bahwa anak belajar dari observasi terhadap lingkungannya, kemudian anak akan mempraktekkan apa yang telah dipelajarinya (Santrock, 2007).

Pengaruh orang tua partisipan tidak hanya sebatas ikut menjadi role model, pola asuh mereka yang cenderung permisif memberi kesempatan yang sangat besar bagi ketiga subjek untuk mencoba merokok karena ketiga subjek merasa perilaku merokok mereka 'direstui' oleh orang tua mereka. Tidak adanya larangan yang tegas atas perilaku merokok yang dimiliki kakak subjek, membuat subjek berpikir bahwa merokok merupakan hal yang diperbolehkan dalam keluarganya. Ayah subjek pun hanya mensyaratkan anaknya sudah bekerja jika ingin merokok. Hal tersebut membuat subjek berani untuk merokok tanpa sepengetahuan orang tuanya, karena partisipan beranggapan bahwa pada dasarnya dirinya boleh merokok jika sudah bekerja. Namun karena belum bekerja, subjek merokok secara diam-diam tanpa sepengetahuan orang tuanya. Hal ini juga menjadi salah satu faktor pendorong perilaku merokok pada subjek. 
Faktor terakhir yang hanya memiliki sedikit pengaruh atas keputusan merokok yang diambil ketiga subjek adalah iklan. Iklan baik dalam media cetak maupun elektronik memiliki pengaruh terhadap perilaku merokok ketiga partisipan meskipun pengaruhnya tidak terlalu signifikan. Iklan rokok yang selalu menampilkan citra diri macho, lelaki perkasa, ataupun orang-orang dengan kemampuan sosial interpersonal yang baik mampu membuat ketiga subjek tersugesti untuk mencoba merokok. Iklan yang paling menarik bagi ketiga subjek adalah iklan yang menampilkan tema sepak bola dimana sepak bola adalah salah satu permainan favorit mereka.

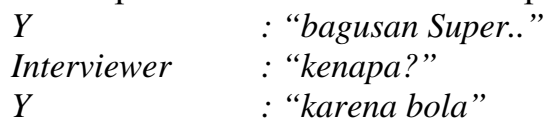

Meskipun iklan rokok tidak memberi pengaruh yang cukup signifikan, bukan berarti iklan rokok tidak memberi pengaruh sama sekali. Iklan rokok tetaplah memunculkan rasa ingin merokok pada diri subjek dan akhirnya membuat subjek memutuskan untuk membeli rokok dan merokok.

Merujuk pada penjelasan di atas, maka dapati ditarik kesimpulan bahwa faktor utama yang membuat ketiga subjek memutuskan untuk merokok adalah ajakan teman-teman sepermainan untuk mencoba merokok. Selain karena ajakan, rasa ingin tahu yang cukup tinggi dari ketiga subjek pun menjadi motif pendorong bagi munculnya perilaku merokok pada ketiga partisipan. Disamping itu, adanya anggota keluarga yang merokok memantapkan keputusan dari subjek untuk mencoba merokok. Anggota keluarga yang merokok menandakan bahwa merokok bukanlah hal yang dilarang dalam keluarganya, dengan demikian tidak ada salahnya bagi subjek untuk mencoba merokok.

Setelah muncul perilaku merokok, subjek mempertahankan perilaku merokok tersebut karena ingin terlihat menarik. Dengan terlihat menarik, subjek merasa lebih percaya diri dan mampu bergaul dengan lingkungannya. Selain itu, responden mempertahankan perilaku merokok karena orang tuanya yang cenderung bersikap permisif terhadap perilaku merokok kakak dari subjek. Kakak subjek yang tidak dilarang merokok oleh orang tuanya, meyakinkan subjek bahwa merokok tidaklah salah. Dengan demikian, tidak menjadi masalah jika subjek pun akhirnya memilih untuk merokok. Faktor iklan memiliki perannya sendiri dalam memunculkan dan mempertahankan perilaku merokok pada ketiga subjek. Iklan-iklan rokok yang banyak dilihat subjek baik di media elektronik maupun spandukspanduk di jalanan terkadang menimbulkan keinginan untuk merokok pada diri ketiga subjek.

Melihat penjelasan diatas, sebagian besar faktor pendorong perilaku merokok yang muncul pada ketiga subjek termasuk dalam kategori motif sosiogenik. Maksud dari motif sosiogenik adalah motif atau daya pendorong perilaku yang muncul atau terbentuk karena hubungan antar-pribadi, hubungan antar-kelompok atau nilai-nilai sosial, dan pranata-pranata (Sherif \& Sherif dalam Sarwono,2002). Dengan demikian, dapat disimpulkan bahwa perilaku merokok pada ketiga subjek tidaklah murni muncul atas dasar faktor kepribadiannya, melainkan lebih karena faktor lingkungan yang mempunyai andil besar dalam memunculkan perilaku merokok pada ketiga subjek tersebut.

Tabel 3 Faktor Pendorong Perilaku Merokok

\begin{tabular}{lcc}
\multicolumn{1}{c}{ Faktor Pendorong } & Late childhood & Remaja \\
\hline Pengaruh teman & $\sqrt{ }$ & $\sqrt{ }$ \\
Faktor kepribadian & $\sqrt{ }$ & $\sqrt{ }$ \\
Pengaruh orang tua & $\sqrt{ }$ \\
Pengaruh iklan & $\sqrt{ }$ & $\sqrt{ }$ \\
\hline
\end{tabular}

Tabel diatas menjelaskan bahwa faktor pendorong perilaku merokok pada ketiga subjek dan remaja memiliki kesamaan yang terdiri dari pengaruh orang tua, pengaruh teman, faktor kepribadian dan pengaruh iklan. 
Mu'tadin (dalam Nasution, 2007) mengungkapkan bahwa semakin banyak remaja merokok, maka semakin besar pula kemungkinan teman-temannya adalah perokok juga dan demikian sebaliknya. Hal ini sejalan dengan penemuan peneliti, bahwa perilaku merokok pada 3 subjek late childhood dalam penelitian ini sangat dipengaruhi oleh teman-temannya yang merupakan perokok. Pengaruh teman merupakan faktor pendorong utama pada ketiga subjek ini untuk merokok.

Hal ini sesuai dengan perkembangan psikososial pada usia late childhood yang menganggap teman sebagai hal yang paling penting (Papalia, Olds, \& Feldman, 2007). Apa yang dikatakan baik oleh temannya, akan diikuti oleh late childhood tersebut karena significant person bagi mereka adalah teman-temannya. Faktor pribadi juga merupakan salah satu faktor pendorong perilaku merokok pada late childhood. Rasa ingin tahu yang tinggi mendorong ketiga subjek untuk mencoba merokok. Hal ini terjadi pula pada diri remaja dimana remaja merokok karena rasa ingin tahu yang tinggi atau ingin melepaskan diri dari rasa sakit, membebaskan diri dari kebosanan (Mu'tadin dalam Nasution, 2007).

Anak-anak yang berasal dari keluarga permisif, lebih besar kemungkinan untuk merokok dibanding anak-anak dari keluarga konservatif (Mu'tadin dalam Nasution, 2007). Orang tua yang permisif cenderung untuk tidak melarang perilaku anak-anaknya selama itu tidak merugikan. Bagi ayah dari ketiga subjek yang terlibat, perilaku merokok bukanlah sesuatu yang buruk bagi mereka dikarenakan sejak kecil mereka telah belajar merokok dan mereka pun hidup di lingkungan perokok. Untuk itu, mereka merasa bahwa tidak perlu melarang anak-anak mereka untuk merokok selama anakanak itu dianggap sudah cukup besar dan mampu mempertanggungjawabkan pilihan hidup mereka sendiri.

Faktor iklan merupakan salah satu pemicu perilaku merokok pada remaja (Mu'tadin dalam Nasution, 2007). Hal ini tidak secara signifikan terjadi pada ketiga subjek. Pada 3 orang late childhood yang menjadi subjek dalam penelitian mengungkapkan bahwa melihat iklan rokok tidak selalu memunculkan keinginan merokok pada mereka. Hal ini berbeda dengan penemuan oleh Komnas Perlindungan Anak dalam survei tentang remaja yang merokok. Survei tersebut menghasilkan fakta bahwa 91.7 \% remaja merokok dikarenakan iklan rokok.

Pertanyaannya adalah mengapa faktor pendorong perilaku merokok pada remaja dan ketiga late childhood yang menjadi subjek memiliki kesamaan yang cukup identik. Hal ini mungkin dikarenakan usia ketiga subjek berada pada akhir masa late childhood yaitu 11 tahun. Masa akhir late childhood merupakan masa transisi ke masa remaja. Hal ini menyebabkan ketiga late childhood memiliki sedikit pola perkembangan remaja. Dengan demikian, tidak mengherankan jika ketiga subjek memiliki kesamaan yang cukup identik pada faktor pendorong perilaku merokok dengan remaja.

Hasil penelitian ini memiliki dampak langsung terhadap bidang akademisi. Masih jarangnya penelitian tentang perilaku merokok pada late childhood, membuat hasil penelitian ini cukup memberi sumbangsih dalam hal literatur terkait perilaku merokok pada late childhood. Hasil penelitian ini bisa menjadi masukan bagi peneliti lain yang ingin meneliti tentang perilaku merokok pada late childhood. Selain itu, hasil penelitian ini dapat dikembangkan menjadi penelitian-penelitian baru untuk memperkaya literatur tentang perilaku merokok pada late childhood. Hasil penelitian ini juga memiliki dampak tidak langsung pada masyarakat, yaitu dengan menambah pengetahuan mereka tentang faktor-faktor yang menjadi pendorong perilaku merokok pada late childhood. Setelah mengetahui faktor-faktornya, masyarakat dapat berupaya untuk mengontrol munculnya faktor-faktor pendorong perilaku merokok yang disebabkan oleh lingkungan. Adanya kontrol langsung dari masyarakat, akan berdampak pada berkurangkan jumlah perokok late childhood di Indonesia terutama di Jakarta. 


\section{PENUTUP}

Penelitian ini pada akhirnya menemukan bahwa yang menjadi motif atau faktor pendorong mengapa ketiga subjek late childhood merokok adalah faktor teman, factor pribadi, faktor keluarga, dan faktor iklan. Faktor teman merupakan faktor pendorong paling kuat bagi ketiga subjek untuk merokok karena teman merupakan significant person bagi ketiga subjek yang terlibat dalam penelitian. Keluarga yang merokok pun menjadi faktor yang cukup penting karena bersama dengan teman-teman partisipan, mereka menjadi role model dalam hal perilaku merokok bagi ketiga subjek. Selain menjadi role model, orang tua yang cenderung permisif dan mengabaikan membuat ketiga subjek merasa bahwa merokok bukanlah hal yang negatif dan patut untuk dicoba.

Rasa ingin tahu yang tinggi serta keinginan untuk terlihat menarik merupakan faktor yang cukup menentukan pula dalam perilaku merokok pada ketiga subjek. Rasa ingin tahu yang tinggi membuat ketiga subjek pada akhirnya berani memutuskan untuk merokok, dan keinginan untuk terlihat menarik pada akhirnya membuat mereka mempertahankan perilaku merokok mereka. Faktor iklan merupakan faktor yang tidak berpengaruh terlalu signifikan pada perilaku merokok ketiga subjek. Ketiga subjek merasa iklan rokok tidak selalu membuat mereka ingin merokok meskipun terkadang timbul keinginan untuk merokok setelah melihat iklan rokok. Dengan demikian, iklan rokok tidak bisa dianggap sebagai faktor yang cukup signifikan dalam menimbulkan perilaku merokok pada ketiga subjek.

Faktor pendorong perilaku merokok pada ketiga subjek late childhood dan remaja memiliki cukup banyak kesamaan. Faktor teman merupakan faktor pendorong pertama pada perilaku merokok remaja dan ketiga partisipan. Teman-teman yang merokok menyebabkan baik remaja maupun ketiga partisipan late childhood mencoba untuk merokok juga. Hal ini dikarenakan teman-teman yang merokok cenderung mengajak teman-temannya yang belum merokok untuk ikut merokok. Selain mengajak, teman-teman yang sudah merokok sering kali mengajarkan teman-temannya yang belum merokok dengan menjadi role model. Faktor keluarga menjadi faktor pendorong terkuat kedua. Adanya anggota keluarga yang merokok secara tidak langsung ikut menjadi role model bagi remaja dan ketiga subjek untuk ikut merokok. Sikap mengbaikan dan cenderung permisif orang tua terhadap perilaku merokok anak-anaknya pun ikut menjadi pemicu munculnya perilaku merokok pada ketiga subjek. Faktor pribadi remaja dan ketiga subjek yang cenderung memiliki rasa ingin tahu yang tinggi serta ingin dipandang menarik oleh lingkungannya turut andil dalam memicu perilaku merokok pada diri mereka.

Faktor pendorong terakhir adalah faktor iklan. Efek dari faktor iklan cenderung berbeda pada remaja dan ketiga partisipan. Pada remaja, iklan menjadi faktor yang cukup signifikan dalam memunculkan perilaku merokok. Hal ini dibuktikan oleh Komnas Perlindungan Anak dalam surveinya terhadap remaja merokok di wilayah Jakarta. Survei tersebut membuktikan bahwa iklan rokok berpengaruh sebesar $91.7 \%$ dalam memunculkan perilaku merokok pada remaja berusia 13-15 tahun (Total Ban, 2009). Ketiga subjek pada dasarnya tidak terlalu terpengaruh iklan rokok dalam kaitannya dengan perilaku merokok. Iklan rokok terkadang memunculkan keinginan merokok pada diri subjek setelah melihatnya, namun iklan rokok tidak memicu munculnya perilaku merokok pada diri subjek. Hal ini berarti iklan rokok tidak memberi pengaruh yang cukup signifikan bagi munculnya perilaku merokok pada ketiga subjek

Saran pengembangan bagi peneliti lain yang ingin melakukan penelitian serupa atau ingin melanjutkan penelitian yang sudah ada adalah dengan melakukan penelitian dengan menggunakan desain penelitian kuantitatif agar diperoleh generalisasi mengenai motif atau factor pendorong perilaku merokok pada latechildhood. Disarankan juga untuk penelitian selanjutnya dengan menggunakan beberapa variabel peneltian dan subjek yang lebih banyak. 
Saran bagi masyarakat dan pemerintah serta lembaga-lembaga yang peduli terhadap pencegahan dan penanganan perilaku merokok pada late childhood adalah dengan melakukan intervensi sedini mungkin terhadap late childhood yang merokok. Ketiga partisipan late childhood yang terlibat dalam penelitian ini tidak mengetahui jelas bahaya yang disebabkan oleh rokok. dengan memberikan informasi yang jelas mengenai bahaya merokok, diharapkan late childhood yang merokok dapat mengurangi atau menghentikan perilaku merokok mereka. Temuan penelitian ini adalah keluarga yang merokok bisa menjadi role model bagi perilaku merokok late childhood yang bersangkutan. Dengan bdemikian disarankan pula untuk melakukan intervensi kepada keluarga melalui penyuluhan-penyuluhan yang intensif dan informatif, diharapkan keluarga terutama orang tua dapat memiliki pola pikir yang lebih terbuka mengenai bahaya merokok sejak dini. Ketersediaan dan mudahnya mengakses rokok menjadi factor yang memicu anak dan remaja merokok,oleh karena itu penelitian ini dapat memberikan masukan bagi kebijakan pemerintah dengan melakukan intervensi melalui pelarangan penjualan dan pemasanagan iklan rokok.

\section{DAFTAR PUSTAKA}

Chaplin, J. P. (2006). Kamus Lengkap Psikologi (Kartini Kartono, Trans.). Jakarta: RajaGrafindo Persada.

Davidson, G. C., Neale, J. M., \& Kring, A. M. (2006). Psikologi Abnormal. (9 ${ }^{\text {th }}$ ed). Penerjemah: Noermalasari Fajar. Jakarta: RajaGrafindo Persada.

Donovan, J.E. \& Jessor, R. (1985). Structure of problem behavior in adolescence and young adulthood. Journal of Consulting and Clinical Psychology, 53(6), 890-904.

Ganyong. (2010, Januari 23). Indonesia, Sorga Bagi Perokok dan Produsen Rokok. Kompas. Retrieved September 17, 2010, from http://kesehatan.kompasiana.com/group/medis/2010/01/23/indonesia-sorga-bagi-perokok-danprodusen-rokok/

Iqbal, M. F. (2008). Perilaku merokok remaja di lingkungan rw.22 kelurahan Sukatani kecamatan Cimanggis Depok Tahun 2008. (Tugas akhir tidak dipublikasikan). Program Sarjana Fakultas Kesehatan Masyarakat Universitas Indonesia.

Komasari, D. \& Helmi, A, F. (2000). Faktor-Faktor Penyebab Perilaku Merokok pada Remaja. Jurnal Psikologi, 28, 37-47.

Messwati, E. D. (2008, April 16). Lebih 43 Juta Anak Hidup Dengan Perokok. Kompas. Retrieved September 17, 2010, from http://kesehatan.kompas.com/read/2008/04/16/19284445/Lebih.43.Juta.Anak.Hidup.dengan.P erokok.

Nasution, I. K. (2007). Perilaku Merokok pada Remaja. (Tugas akhir tidak dipublikasikan). Program Sarjana Fakultas Kedokteran Universitas Sumatera Utara

Ogden, J. (2000). Health Psychology. Buckingham: Open University Press

Papalia, D. E., Olds, S. W., \& Feldman, R. D. (2007). Human Development (10 ${ }^{\text {th }}$ ed). New York: McGraw Hill

Purwoko. (2010, Desember 31). Pertumbuhan Ekonomi DKI Lampaui Nasional. Retrieved Januari 19, 2011 from http://www.jakarta.go.id/jakv1/item/halaman/10/0/3832 
Safitri, D. (2010). Sponsor dan Iklan Rokok Belum Terganti. Retrieved September 16, 2010 from http://www.bbc.co.uk/indonesia/laporan_khusus/2010/05/100521_tobacco3sponsorship.shtml

Santrock, J. W. (2007a). Child Development $\left(11^{\text {th }}\right.$ ed). New York: McGraw Hill

Santrock, J.W. (2007b). Psikologi Pendidikan (2 ${ }^{\text {th }}$ ed) (Tri Wibowo B. S., Trans.) Jakarta: Prenada Media Group

Santrock, J. W. (2008). Live-Span Development (11 ${ }^{\text {th }}$ ed). New York: McGraw Hill

Sarwono, S. W. (2002). Psikologi Sosial: Individu dan Teori-Teori Psikologi Sosial. Jakarta: Balai Pustaka.

Shaughnessy, J. J., Zechmeister, E. B., \& Zechmeister, J. S. (2009). Research Method in Psychology. $\left(8^{\text {th }}\right.$ ed). New York: McGraw Hill.

Soerojo, W., Ahsan, A., Nurwati, S., Budiantoro, S., \& Muhammad, S. (2007). Profil Tembakau Indonesia. Jakarta: Tobacco Control Support Center (TCSC)-IAKMI.

Sugiyono. (2009). Metode Penelitian Kuantitatif, Kualitatif, dan R\&D. Bandung: Alfabeta

Total Ban. (2009, Desember 20). Anak Merokok Karena Iklan Rokok. Retrieved November 21, 2010, from http://www.total-ban.org/node/9

Wu, L. T., \& Anthony, C. J. (1999). Tobacco Smoking and Depressed Mood in Late Childhood and Early Adolescence. American Journal of Public Health, 89, 1837-1840. 